\title{
THEORY OF LITERATURE
}

DOI https://doi.org/10.30525/978-9934-26-110-7-47

\section{ТЕАТР КОДУЄ ІСТОРІЮ, АБО ЯК СТРАТЕГІЇ «ТЕАТРУ В ТЕАТРІ» ПРАЦЮЮТЬ НА ПЕРЕОСМИСЛЕННЯ БІОГРАФІЧНИХ ПЕРСОНАЛІЙ}

\author{
Бондарева О. С. \\ доктор філологічних наук, професор, \\ головний науковий співробітник \\ Київський університет імені Бориса Грінченка \\ м. Київ, Украӥна
}

У цифрову епоху театрові важко конкурувати з масовими візуальними та видовищними мистецтвами, відтак одним із шляхів демонстративного утвердження власної актуальної форматності та суб'єктності він обирає нарочиту візуалізацію самовідтворення, яка у теоретичних працях розглядається переважно у двох форматах: або вузько - як застосування конструктивного принципу «театру в театрі», коли певний сюжет або драматургічний твір (відомий чи невідомий) перед читачами/глядачами розігрує театральний колектив, у якому є окремі власні колізії акторів, режисера, інших працівників сцени; або широко через концепцію метатеатральності як універсального формату саморепрезентації театру.

$\mathrm{y}$ першому випадку йдеться про здатність театральних елементів продовжувати «внутрішню п'єсу в рамках прем'єри», сприяти появі «зображуваної дійсності в іiі театралізованому варіанті» [8, с. 246], переглядати «внутрішні естетичні резерви всеохопного концепту «Театр» і семантичних полів, пов'язаних з його сутнісним наповненням» [1, с. 454], а також розмивати кордони «між залою і сценою», між виставою як «результатом невидимої праці» та «перформативними демонстраціями» iї «привселюдного створення» [1, с. 455], а сам текст п'єси сприймати скоріше як «драматургічний матеріал», наближений до «технічної інструкції, в якій викладено спосіб, що ним можна достукатися до кінцевого адресата - душі глядача або слухача» [6, с. 21]. Позиція «театру в театрі» може інтерпретуватися як своєрідна «метатеатральна рамка», в яку вписується «театральний пласт, пов'я- 
заний із театральними репетиціями й виставами, існуванням театру як живого організму, життєвими - цілком реальними, а не декоративними драмами акторів, режисерів, драматургів» [2, с.193], що дозволяє змінювати модуси драматургічного тексту i увиразнює авторські інтенції, а реципієнта робить співтворцем театрального тексту.

У другому випадку, при очевидній близькості термінів, розглядається загальна метакритична потенційність будь-яких оприявлених театральних структур, їх придатність до концентрації «метатеатральної напруги», конструювання інших полів театрального висловлювання, нових форм театральної комунікації та незвичних іiї модальностей [8, с. 246-248]. Модусом такого теоретизування стає складна «система надконструкцій», що, наприклад, дозволяє створити універсальну типологію метадрами, обгрунтувати іiі критерії та різновиди [4, с. 8-15, 76-85]. 3 цих позицій можна інтерпретувати будь-який драматургічний текст, а не лише той, в який закладено ситуацію «театру в театрі».

Цікавий кумулятивний ефект накладання/резонування/підсилення двох начебто абсолютно автономних художніх реальностей - біографістики та метатеатральності - виникає у сучасній українській драматургії, яка $з$ постколоніальних позицій переосмислює український культурний канон і дискутує і з усталеними драматургічними практиками, і $з$ персональними постатями канону. Тут показовими можна вважати найновіші драматургічні тексти Ярослава Верещака «Пекельна дорога до раю» [3], Володимира Діброви «Куліш» [5] та Олега Миколайчука «Гайдамаки. Інші» [7].

У всіх випадках йдеться про драматургічні біографії великих українців, які розігруються невеличкими театральними колективами: у В. Діброви це всього кілька акторів і режисер; в О. Миколайчука трохи більший осередок, в якому також $є$ режисер, кількість акторів може коливатися від чотирьох до двадцяти і більше, а також передбачено хор з восьми жінок, у дію введено ще робітника сцени; в Я. Верещака модель альтернативного самодіяльного театру, такого собі «антитеатру», який функціонує у підвальному приміщенні, геть не придатному для високого мистецтва.

Персонажі п’єси «Гайдамаки. Інші» працюють 3 текстом поеми «Гайдамаки» Тараса Шевченка та 3 однойменною виставою Леся Курбаса, яку спершу намагаються просто реконструювати, проте «проживають» обидва твори 3 урахуванням українського посттоталітарного досвіду і контекстів XXI століття, відтак колективно створюють новий інтерсеміотичний театральний текст, в якому відбувається ревізія та переосмислення постатей Тараса Шевченка, Миколи Гоголя, Михайла 
Щепкіна, Леся Курбаса, Івана Миколайчука. У двох інших п’єсах актори грають невідомі нам п’єси про досі контроверсійних персонажів української історії та культури, і авторство цих драматургічних партитур належить персонажам, що активно діють на сцені впродовж вистави (у Володимира Діброви йдеться про «ювілейну» п'єсу, яка присвячена Пантелеймону Кулішу і належить перу Режисера, тобто, маємо тривимерний складний образ Автора-Режисера-Актора, а у Ярослава Верещака група ентузіастів втілює драму з особистого архіву персонажа i актора Учителя, присвячену осмисленню постаті Степана Бандери).

Що змінюється у структурі та поетиці подібних драматургічних текстів?

1) Театр не лише як невеличкий людський колектив, а насамперед як Інший простір, стає новим універсальним посередником між текстом та його реципієнтом.

2) Створювана на очах глядачів вистава не обов'язково має бути успішно реалізованим проєктом (як в О. Миколайчука), може завершитися поразкою (у В. Діброви) або мати відкритий фінал (у Я. Врещака).

3) Опосередкованість сприйняття біографічного персонажа робить сам біографічний жанр надзвичайно гнучким та еластичним, додає в його арсенал чимало влучних мінімалістичних художніх ресурсів.

4) «Проживання» театральними персонажами чужих біографічних життів для цих персонажів в усіх випадках стає теургічним, і це сприяє підсиленню впливу вистави на глядача та створює нові рівні взаємодії.

5) При безкінечному тиражуванні театрального кону взагалі знімається питання про межу між сценою і глядацькою залою, відтак театр стає тотальним, а публіка перетворюється на театральну масовку.

6) Тексти такої структури є відкритішими для голосу та інтенцій самих драматургів, аніж традиційна власне біографічна драма.

7) Оформлюються нові модуси театральних репрезентацій: дискутабельність, провокативність, релятивність факту, особистісна інтерпретація, поліморфність, нелінійність, можливість перформативно створити палімпсест.

Таким чином, засвоєння сучасною біографічною драматургією різних метатеатральних стратегій суттєво і невідворотно трансформує сам жанр.

\section{Література:}

1. Бондарева О. Міф і драма у новітньому літературному контексті: поновлення структурного зв'язку через жанрове моделювання. К.: Четверта хвиля, 2006. 512 с. 
2. Васильєв Є. Сучасна драматургія: жанрові трансформації, модифікації, новації. Луцьк: Твердиня, 2017. 532 с.

3. Верещак Я. Пекельна дорога до раю: Маленька п'єса про великий український сюр. Верещак Я. Центрифуга. Варіанти. Збірка п’єс. К.: НЦТМ ім. Л.Курбаса, 2018. С. 65-84.

4. Вісич О. Метадрама: теорія і репрезентація в українській літературі. Луцьк: Вежа-друк, 2018. 340 с.

5. Діброва В. Куліш. П'єса на дві дії. К.: Видавництво «Український пріоритет», 2019.96 с.

6. Гундарс Л. Драматика, или Поэтика рациональности: пер. с латыш. М: Манн, Иванов и Фербер, 2020. 224 с.

7. Миколайчук-Низовець О. Гайдамаки. Інші. Миколайчук-Низовець О. Алхімія часу: Зб. драматургічних творів. К.: Світ знань, 2019. C. 173-216.

8. Паві П. Словник театру. Львів: Видавничий центр ЛНУ імені Івана Франка, 2006. 640 с.

DOI https://doi.org/10.30525/978-9934-26-110-7-48

\title{
АРХЕТИПИЧЕСКИЙ МОТИВ КАК СПОСОБ ПСИХОЛОГИЗАЦИИ ХУДОЖЕСТВЕННОГО ПРОИЗВЕДЕНИЯ (НА ПРИМЕРЕ РОМАНА ДЖ. ХАРРИС «ПЯТЬ ЧЕТВЕРТИНОК АПЕЛЬСИНА»)
}

\author{
Храбан Т. Е. \\ кандидат филологических наук, \\ заведующая кафедрой иностранных языков \\ Военный институт телекоммуникаиий и информатизации \\ Кодола Р. Н. \\ преподаватель кафедры иностранных языков \\ Военный институт телекоммуникаций и информатизации \\ г. Киев, Украина
}

Психолингвистика оказывает значительное влияние на исследования в области художественной литературы. Так, при изучении специфики произведения в центре внимания исследователя часто оказывается изображение внутреннего мира героя, иными словами, психологизм худо- 